\title{
Diffusion of Innovation: Adoption of Learning Management System Technology in Emerging Market Economies
}

\author{
Rashid Khan ${ }^{1}$, Akash Dania $^{2}$, Dialdin Osman ${ }^{3}$ \& Dexter Gettins ${ }^{3}$ \\ ${ }^{1}$ King Fahd University of Petroleum and Minerals, Dhahran, Saudi Arabia \\ ${ }^{2}$ College of Business, Delaware State University, Dover, Delaware, USA \\ ${ }^{3}$ College of Business, Alabama State University, Montgomery, Alabama, USA \\ Correspondence: Akash Dania, Ph.D., College of Business, Delaware State University, Dover, DE 19901, USA.
}

Received: June 8, 2020

Accepted: December 5, 2020

Online Published: December 28, 2020

doi:10.5430/afr.v10n1p1

URL: https://doi.org/10.5430/afr.v10n1p1

\begin{abstract}
The market for the next-generation learning management system (LMS) for higher education is poised to grow by the US \$3.04 billion during 2020-2024 (MarketWatch, 2020), creating technological opportunities in the higher education learning landscape particularly due to growth in remote learning due to COVID-19 pandemic. This rapid growth necessitates an urgent need to integrate technology with the instructional design in academic programs at the Higher Educational Institutes (HEIs) globally. The existing literature on the LMS-suggests a considerable resistance among the instructor group towards technology adoption in pedagogic strategy. LMS has been in existence for almost two decades, however, they have not been leveraged to their full potential. An understanding of the nature of technology adoption among instructor group is even more pronounced for the HEIs of emerging market economies (EMEs). An efficient and technology-inspired educational construct will boost the overall competitiveness of the EME's in their respective population skill development and attracting foreign investments for industrial growth. Moreover, given the lessons learned from the epidemiological uncertainties, such as most recently, the COVID-19 pandemic, educators should be prepared to utilize LMS to their full potential. The purpose of this study is to investigate the barriers and motivators in LMS adoption among emerging market economy HEIs and to propose a technology adoption model based on the Unified Theory of Acceptance and Use of Technology (V. Venkatesh et. al., 2012). The results of this study suggest implementing a dynamic feedback mechanism of technology adoption by instructors, and the need for HEIs to articulate strategic plan goals that focus on faculty professional development in the use of technology to build confidence among instructor group to enable the adoption of technology for instruction.
\end{abstract}

Keywords: LMS (Learning Management System), technology adoption, higher education, teaching, and learning

\section{Introduction}

Technology-based learning has a strong potential to provide the EMEs with a tech-savvy workforce leading to overall competitiveness in attracting Foreign Direct Investment (FDI) and establishing new industry thus fueling economic growth. Setting technology-based higher education standards are also vital to the EMEs as these economies shift towards more value-added sectors. Several HEIs throughout EMEs are now distributing computer devices to student populations reflecting an understanding of the importance of digital learning and staying connected via an LMS learning pedagogy. Given the lesson learned from the epidemiological uncertainties, such as from the COVID-19 pandemic, administrators and educators at HEIs should be prepared for the likelihood that online learning will continue to be the norm for many months and therefore be prepared to effectively deliver educational sessions using LMS. COVID-19 era has demonstrated that LMS based learning infrastructure may be a viable alternative to large brick-and-motor institutes which are difficult to build for cash limited emerging economies. LMS based learning also has potential for wider coverage, essentially providing opportunities to less developed areas of an emerging economy. However, for an effective brick-and-motor alternative, it is important to understand the barriers and motivators for instructors to effectively adopt LMS based instruction delivery. Utilizing the UTAUT2 model proposed by V. Venkatesh, J. Thong, \& Xu (2012), we investigate the barriers and motivators for influencing technology adoption among instructors. The theoretical framework for designing the conceptual model was the Unified Theory of Acceptance and Use of Technology 2 (UTAUT2). Venkatesh et al. (2012) proposed UTAUT2 as a framework to explain a person's behavior while using technology. 


\subsection{Objectives of the Study}

Using higher educational institutes (HEIs) in the Eastern province of Saudi Arabia, the purpose of this study is to explore the barriers and motivators in the adoption of Learning Management Systems (LMS) and the UTAUT2 model (V. Venkatesh, J. Thong, \& Xu, 2012). In general, the two main objectives of this study are to explore the variables (i.e. barriers and motivators) influencing the technology adoption, namely the LMS adoption among teaching faculty at HEIs and, to propose a new technology adoption model using the UTAUT2 for the adoption of new technology in educational settings.

\subsection{Statement of Problem}

Higher learning institutes in the EMEs are making huge investments in infrastructure, equipment, and faculty professional development to improve the quality of education. For example, in the case of Saudi Arabia HEIs, LMS systems have been made available for many years at Dammam Community College and KFUPM (King Fahd University of Petroleum and Minerals). However, LMS is not being used with its full potential by the faculty at these Saudi Arabian faculty and therefore by the students (Khan \& Adams, 2016). An understanding of the barriers and motivators of LMS adoption by taking the example of Saudi Arabian HEI will allow us a better understanding of the barriers and motivators in technology adoption among faculty of emerging market economies. The result of this study will be of importance to academicians, practitioners, and policymakers.

\section{Literature Review}

\subsection{Technology in Education}

Today, technology influences almost all facets of life at an individual level, at the organizational, and social levels. The educational system has a deeper impact on the economy and society by providing students with the learning tools they require to succeed and by creating innovations through research. While business, economy, and society all have a profound impact on the educational system. The use of LMS in higher education institutions is growing (Gautreau, 2011). The adoption of LMS for web-based instruction continues to increase in higher education. Prior research indicates that the use of LMS is growing in higher education, but LMS is not being used with its full potential by many lecturers (Bongalos, Bulaon, Celedonio, Guzman, \& Ogarte, 2006).

\subsection{What is a Learning Management System?}

LMS is one of the best e-learning platforms which assist with virtual course delivery (Sharma et al., 2011). The term Virtual learning environment is also sometimes used for CMS or LMS (Dutton, Cheong, \& Park, 2004). The term LMS or Learning Management System is also known as Virtual Learning Environment (VLE) or Course Management System (CMS) refers to an e-learning environment that provides the facilities to the instructors to manage their courses and interact with learners through variety of the tools available within LMS. Such tools include interaction tools (such as messaging, emails, discussion boards, and virtual chat for communication with students) and course delivery (such as uploading syllabus, course materials, assignments, and assessments. Prior research indicates that the use of the Learning Management System (LMS) is growing in higher education (Gautreau, 2011) but LMS is not being used with its full potential by most of the teaching faculty (Dutton, CheonStrand \& Hughes, 2012). As the historical review shows that many LMS systems were developed during the past two decades. WebCT $^{\mathrm{TM}}$ joined Blackboard ${ }^{\mathrm{TM}}$ and owned the largest share in the market. In 1999 Desire2Learn $^{\mathrm{TM}}$ and Moodle started competing with other LMSs. As an open-source, Moodle has made excellent success after Blackboard ${ }^{\mathrm{TM}}$.

Originated in 1997, Blackboard ${ }^{\mathrm{TM}}$ offers learning software applications and other teaching and learning services. Founded in 1997, Blackboard ${ }^{\mathrm{TM}}$ is one of the most popular commercial LMS systems. Blackboard ${ }^{\mathrm{TM}}$ currently offers six platforms to improve different aspects of education: Blackboard Learn ${ }^{\mathrm{TM}}$ (an LMS), Blackboard Collaborate ${ }^{\mathrm{TM}}$ (a virtual classroom for synchronous instruction at a distance), Blackboard Connect ${ }^{\mathrm{TM}}$ (enables sharing time-sensitive information via voice, text, email, and social media), Blackboard TransactTM (offers students a secure way to shop on and off-campus using their ID card), Blackboard AnalyticsTM (enables institution leaders to have easy, self-service access to important data), and Blackboard Mobile ${ }^{\mathrm{TM}}$ (a mobile version of the LMS) (Blackboard ${ }^{\mathrm{TM}}$, 2012).

Modular Object-Oriented Dynamic Learning Environment (Moodle) is a free open-source course management system designed using sound pedagogical principles that helps educators create effective online learning communities. It is a global development project designed to support a social-constructionist framework of education (Moodle, 2010). Moodle is open-source software that has developed as a Ph.D. research project at the Curtin University of Technology in Perth, Western Australia by Martin Dougiamas in 1999. Moodle is considered to be a 
high-value educational tool in higher education. Moodle affords instructors with the tools to promote and manage online learning.

\subsection{UTAUT2: A Proposed Model for LMS Adoption}

Various models have been developed to investigate factors that influence the adoption of new technology (Nistor, Lerche, Weinberger, Ceobanu, \& Heymann, 2014). These technology adoption models are used in various research studies for predicting user behaviors in accepting and adopting technology in teaching (Dulle \& Minishi-Majanja, 2011). This study is based on the Unified Theory of Acceptance and Use of Technology (UTAUT) model. The UTAUT model developed by Viswanath Venkatesh, Morris, Davis, \& Davis (2003) is the most widely used in the field of ITC acceptance. The UTAUT theory tends to explain the 'intention' to 'use' an information technology system. This model was proposed by Venkatesh et.al., (2003) and demonstrates great promise for understanding the acceptance of information systems. Venkates et. al. (2003) describes technology acceptance research as the most mature research area in IS literature. Recently Venkatesh and team members modified UTAUT to the UTAUT2 model by including new dimensions in the UTAUT model.

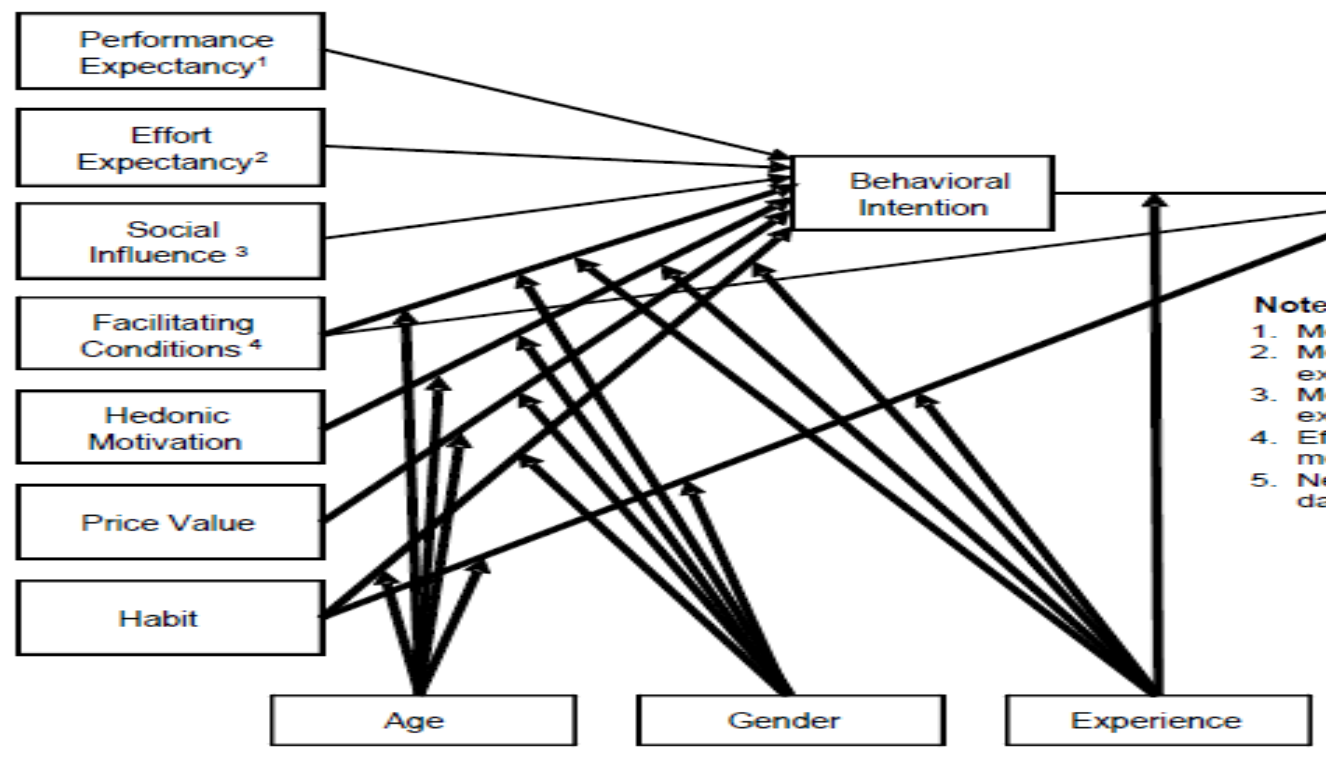

Figure 1. UTAUT2 model byVenkatesh et al (2012)

\section{Methodology}

For the pilot study, a self-administrated survey questionnaire was developed in light of the UTAUT2 questionnaire. The survey questionnaire was shared in Google Docs for selected faculty at DCC and KFUPM. For the Pilot study, paper and electronic-based survey questionnaires were distributed randomly to 45 (DCC and KFUPM) faculty. The participants in the pilot study were asked to complete the survey and provide feedback on difficulties and barriers in the adoption of LMS technology. Data were collected from faculty (KFUPM and DCC) and analyzed qualitatively based on their written and verbal responses. Out of 45 distributed questionnaires, 18 responses were received from DCC and 21 responses were received from KFUPM faculty. Paper-based produced 9 more responses. Hence total no of responses is 39. It was found that out of 39 faculty, 23 were adopters and 16 were non-adopters of LMS as shown:

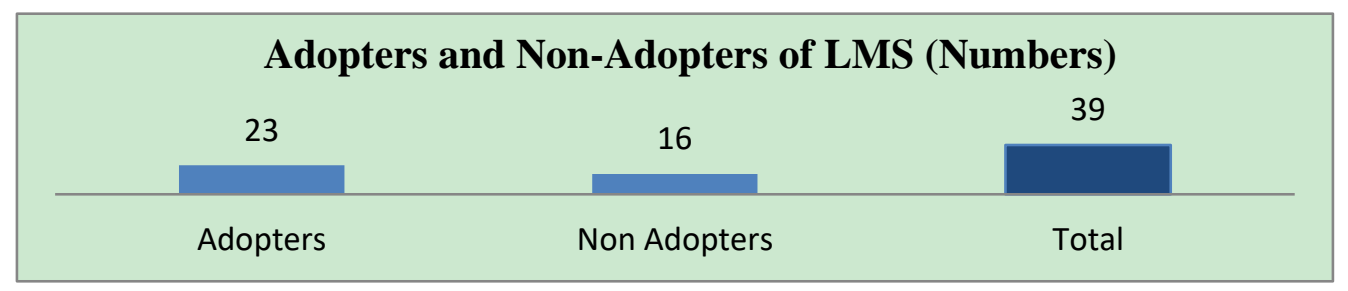

Figure 2. Adopters \& Non-Adopters (DCC \& KFUPM)

Based on the results of the survey questionnaire, a Focus Group Discussion (FGD) was conducted on the adoption of LMS in Saudi Higher Education. The interview questions for FGD were adapted from Venkatesh et al., (2012) and were adjusted to the teaching and learning environment. The collected data from full-time teaching faculty were 
analyzed using thematic analysis for "identifying, analyzing, and reporting patterns (themes) within data" (Braun \& Clarke, 2006).

For FGD, a list of names of the instructors was prepared and invitations were sent to 21 instructors. Twelve instructors confirmed their participation but eight instructors showed up for the FGD. The demography of the instructors is given below as:

Table 1. FGD demography

\begin{tabular}{cccccc}
\hline Participant Name & Coding & Qualification & Departments & Institution & $\begin{array}{c}\text { Age group } \\
\text { (Years) }\end{array}$ \\
\hline Participant 1 & R1 & MS & M.E & KFUPM & $45-50$ \\
Participant 2 & R2 & PhD & CIS & KFUPM & $45-50$ \\
Participant 3 & R3 & PhD & Physics & JUC & $50-55$ \\
Participant 4 & R4 & MBA & BA & DCC & $40-45$ \\
Participant 5 & R5 & MA/MBA & BA/SCM & DCC & $35-40$ \\
Participant 6 & R6 & PhD & EE & DU & $40-45$ \\
Participant 7 & R7 & PhD & CE & PMU & $50-55$ \\
Participant 8 & R8 & MA & English & KFU & $55-60$ \\
\hline
\end{tabular}

\section{Analysis}

The moderator distributed the interview questions and handouts about the UTAUT2 model. The discussion started with the introduction and warm-up question followed by the main questions related to the constructs of the model. Based on FGD, many themes and subthemes emerged. A summary of FGD emerged themes and subthemes are given below as:

Table 2. Themes and subthemes

2A. Main Theme - Performance Expectancy

\begin{tabular}{|c|c|c|}
\hline Main Theme & Sub Theme & Explanation / Comments \\
\hline \multirow[t]{9}{*}{$\begin{array}{l}\text { Performance } \\
\text { Expectancy }\end{array}$} & Centre point of interaction & $\begin{array}{l}\text { - One central point of interaction that connects all activities } \\
\text { and all students with the instructor. }\end{array}$ \\
\hline & & $\begin{array}{l}\text { - Creating a website for downloading slides for students was } \\
\text { more time consuming }\end{array}$ \\
\hline & & $\begin{array}{l}\text { - LMS has a central repository where we can upload teaching } \\
\text { material. }\end{array}$ \\
\hline & Discussion groups & $\begin{array}{l}\text { - Discuss various issues, learn from each other, and keep } \\
\text { up-to-date with all announcements. }\end{array}$ \\
\hline & & $\begin{array}{l}\text { - I can post questions and can invite students to give their input } \\
\text { on that topic through discussions. }\end{array}$ \\
\hline & Multiple learning resources & $\begin{array}{l}\text { - Students can learn from the various supplemental learning } \\
\text { materials in LMS, such as picture files, digital books, pdf } \\
\text { documents. }\end{array}$ \\
\hline & & $\begin{array}{l}\text { - LMS provides a range of study activities that instructors can } \\
\text { choose from. }\end{array}$ \\
\hline & & $\begin{array}{l}\text { - The repetitive activities of the same concept in diverse ways } \\
\text { strengthened their knowledge and retained it in their } \\
\text { memory. }\end{array}$ \\
\hline & Keep organized & - We can organize the entire semester activities such as \\
\hline
\end{tabular}


Improving performance assignments, quizzes, and exam dates ahead of time.

- Posting grades in the grade book regularly helped students to keep organize their study habits and plans.

- LMS is extremely helpful in improving efficiency

- I can perform better using LMS as compared to my traditional teaching.

- An efficient platform for submission of homework at any time and anywhere before the deadline

2B. Main Theme - Effort Expectancy

Main Theme

Sub Theme

Explanation / Comments

\begin{tabular}{|c|c|c|}
\hline \multirow[t]{3}{*}{ Effort Expectancy } & Easy to get familiarized & $\begin{array}{l}\text { - LMS is easy to learn } \\
\text { - Blackboard } 8 \text { and Moodle are easy to learn as compared to } \\
\text { Blackboard } 9 \text {. }\end{array}$ \\
\hline & Straightforward & $\begin{array}{l}\text { - LMS, especially Moodle is straightforward and easy to use } \\
\text { than Blackboard } 9 .\end{array}$ \\
\hline & User friendly & $\begin{array}{l}\text { - Blackboard } 8 \text { is user friendly and flexible. } \\
\text { - Faculty are very comfortable with Blackboard } 8 \text { and } \\
\text { Moodle systems due to their user-friendly interface. }\end{array}$ \\
\hline
\end{tabular}

2C. Main Theme - Social Influence

Main Theme

Sub Theme

Explanation / Comments

\begin{tabular}{|c|c|c|}
\hline \multirow{4}{*}{ Social Influence } & Peer influence & - Adopt new technology due to peer pressure \\
\hline & & - Colleagues encourage and help in using LMS. \\
\hline & students Influence & $\begin{array}{l}\text { - Influenced by the students of other instructors who use } \\
\text { LMS } \\
\text { - students inquire about LMS by giving examples that other } \\
\text { instructors use LMS }\end{array}$ \\
\hline & The interest of higher management & $\begin{array}{l}\text { - Departmental head's encouragement and support to use } \\
\text { LMS in teaching }\end{array}$ \\
\hline
\end{tabular}

2D. Main Theme - Facilitating Conditions

Main Theme

Sub Theme

\section{Explanation / Comments}

- University has good technical support for LMS

Facilitating Technical support

Conditions

LMS Tutorials on the university website
- Good technical support encourages faculty to use LMS in teaching.

- Tutorials about using Blackboard played an important role in learning and adoption decisions. 
Workshops

2E. Main Theme - Hedonic Motivation
- LMS workshops during the orientation program

- Academic development programs

\begin{tabular}{|c|c|c|}
\hline Main Theme & Sub Theme & Explanation / Comments \\
\hline \multirow[t]{2}{*}{$\begin{array}{l}\text { Hedonic } \\
\text { Motivation }\end{array}$} & Entertainment & $\begin{array}{l}\text { - Enjoy the usefulness of LMS by its automated features } \\
\text { such as exams, assignments, and announcements. } \\
\text { - It gives pleasure when students read uploaded slides } \\
\text { before coming to the class and fully understand the lecture. } \\
\text { - I wouldn't call LMS enjoyment. I'm not enjoying it. }\end{array}$ \\
\hline & Is LMS a burden? & $\begin{array}{l}\text { - LMS is not a burden rather it saves our time. } \\
\text { - LMS made life much comfortable and easier }\end{array}$ \\
\hline
\end{tabular}

2F. Main Theme - Habit

\begin{tabular}{ccc}
\hline Main Theme & Sub Theme & \multicolumn{1}{c}{ Explanation / Comments } \\
\hline Habit & LMS as a habit & $\begin{array}{l}\text { LMS has become a habit because faculty can design } \\
\text { courses on LMS, uses LMS for content delivery, for online } \\
\text { exams, and for marking assessments. }\end{array}$ \\
& \begin{tabular}{c} 
It will be very hard to teach without LMS \\
\hline
\end{tabular} \\
\hline
\end{tabular}

2G. Main Theme - Behavioral Intention

Main Theme Sub Theme

Behavioral Intend to keep using intention

Recommend LMS to other faculty

\section{Explanation / Comments}

- Provides ease and comfort, therefore, faculty intend to continue LMS use in the future.

- All faculty are in favor to recommend LMS to other instructors.

- Faculty will convince colleagues how LMS makes the teaching and learning process easier

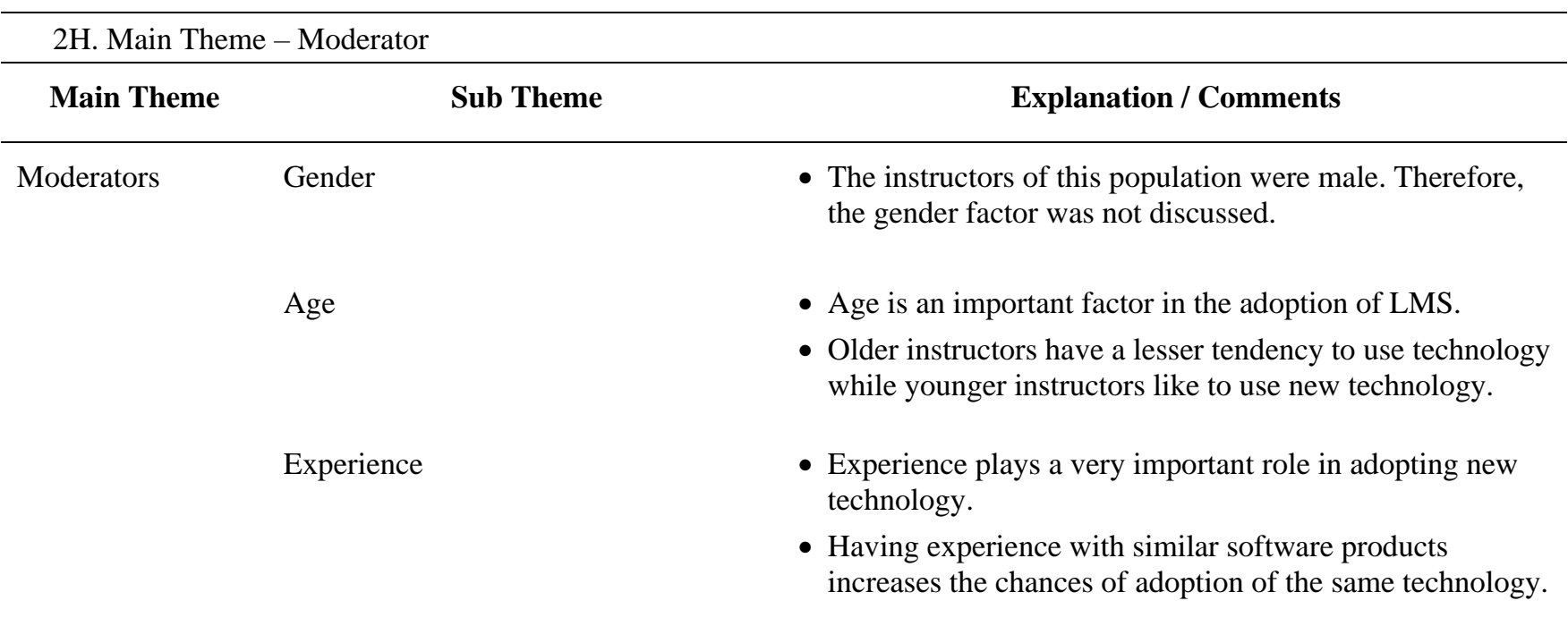


Table 3. Emerged themes and subthemes

\begin{tabular}{lll}
\hline \multicolumn{1}{c}{ Main Theme } & \multicolumn{1}{c}{ Sub Theme } & \multicolumn{1}{c}{ Explanation / Comments } \\
\hline $\begin{array}{l}\text { Emerged } \\
\text { Variables }\end{array}$ & Former Practice & $\bullet \begin{array}{l}\text { The previous familiarity with similar software drove faculty } \\
\text { to accept Blackboard immediately. }\end{array}$ \\
& Good Image & $\begin{array}{l}\text { Good Image (GI) about LMS played a key role in the } \\
\text { adoption of LMS or migrating from WebCT or Moodle to a } \\
\text { new Blackboard system. }\end{array}$ \\
& $\begin{array}{l}\text { Previous good impression and good feelings about WebCT, } \\
\text { faculty started using Blackboard } 9 \text { quickly and without any } \\
\text { fear. }\end{array}$ \\
& $\begin{array}{l}\text { The availability of new technology is a key factor in the } \\
\text { adoption of new technology }\end{array}$ \\
& $\begin{array}{l}\text { Faculty from Asian countries have fewer opportunities but } \\
\text { there is more tendency of adopting new technology in Asian } \\
\text { cultures compared to Arab cultures. }\end{array}$
\end{tabular}

In FGD, instructors mentioned various factors that influenced them to adopt LMS in their teaching. The major factors included usefulness, ease-of-use, social norm (social influence), habit, facilitating conditions, and motivation. The performance expectancy was an important reason for them in accepting the LMS. They also attributed effort expectancy as an important factor for LMS adoption in their teaching. Additionally, facilitating conditions, social influence, and habits were also considered influencing factors in the adoption of LMS. Some participants suggested that former practice, technology availability, and good image of previous versions of WebCT supported them to adopt a new version of the Blackboard system more quickly. Former practice, good image, and technology availability have emerged as new constructs.

Based on the above FGD, the following model is proposed:

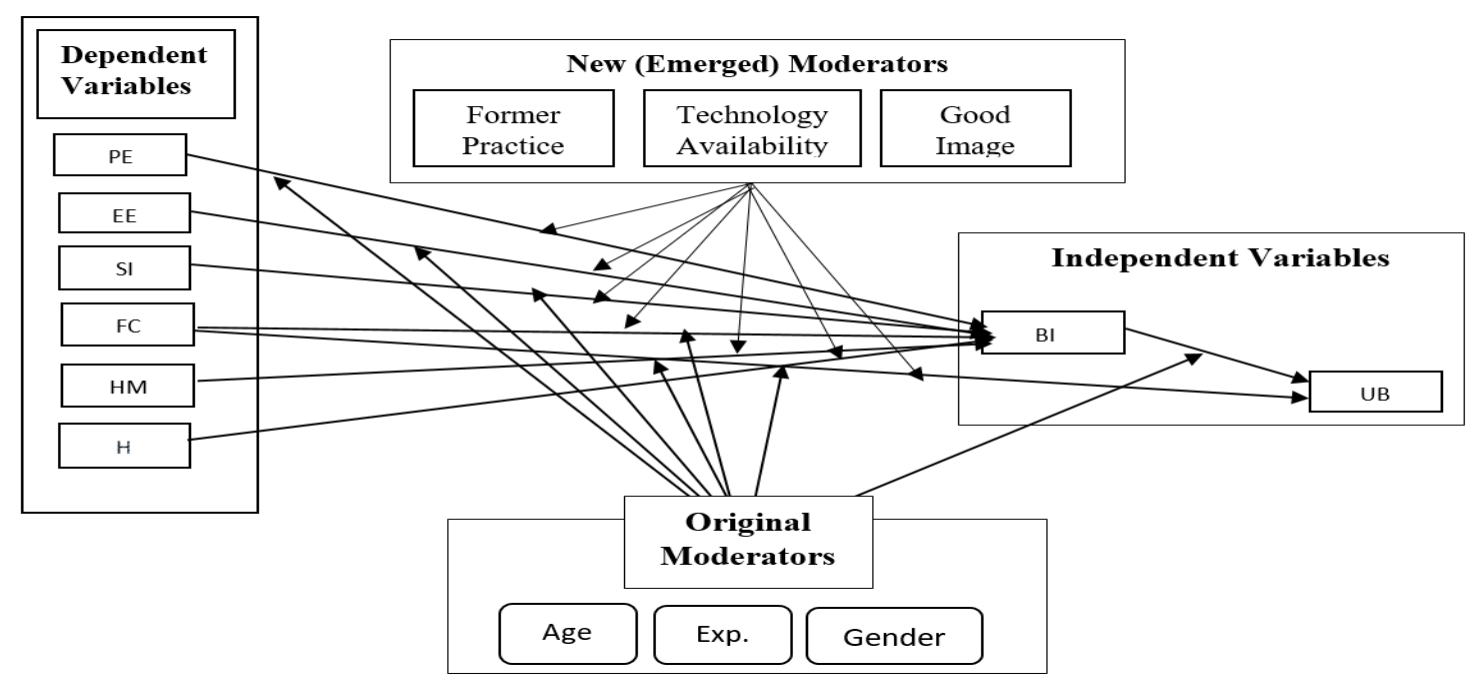

Figure 3. Proposed Model

This research provides an understanding of how instructors perceive LMS features advantageous for teaching and learning. The key advantages of using LMS indicated by instructors are summarized as follows:

The benefits identified by faculty were: Ease for instructors, Ease for students, Improved quality of teaching and learning, Immediate feedback, Easy Interaction using e-mails, chat rooms and messaging system, Automated 
assessments and grade book, and Course management.

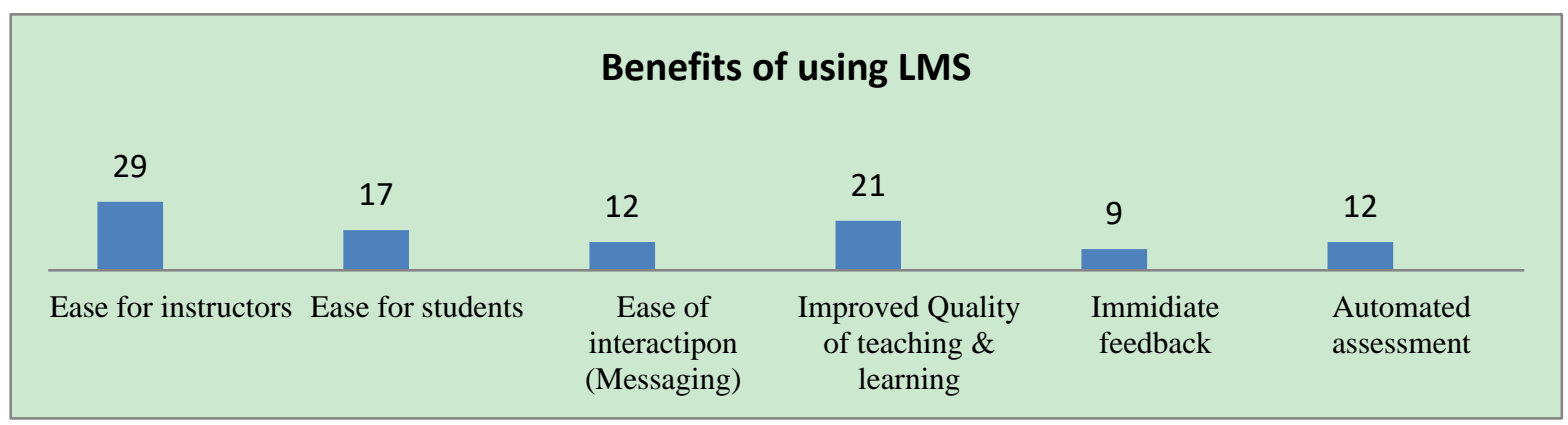

Figure 4. Benefits of LMS adoption

This study also identified many barriers to the adoption of LMSs. During the FGD, the faculty were asked the reasons (barriers) for the non-adoption of LMS.

Question: What are your concerns and difficulties/barriers regarding LMS adoption?

The purpose of this question was to know key barriers and motivators of LMS adoption at HEIs. For this open-ended question, various responses were received. The following are the main themes/comments generated from the discussion:

- I don't have training

- LMS is compatible with the needs of my course

- I fear to lose my material

- I don't trust technology

- I don't like technology

- My teaching load is high

- I don't have time

- I will not be able to cover my syllabus in depth
- I am very busy

- I don't want to spend my time developing LMS material

- Students prefer real-world material

- My life is simpler without using LMS

- LMS is not available for my department

- How about its support if I am stuck with LMS?

- Students don't like the idea of online teaching

All responses were merged based on similarity and are presented in the following graph:

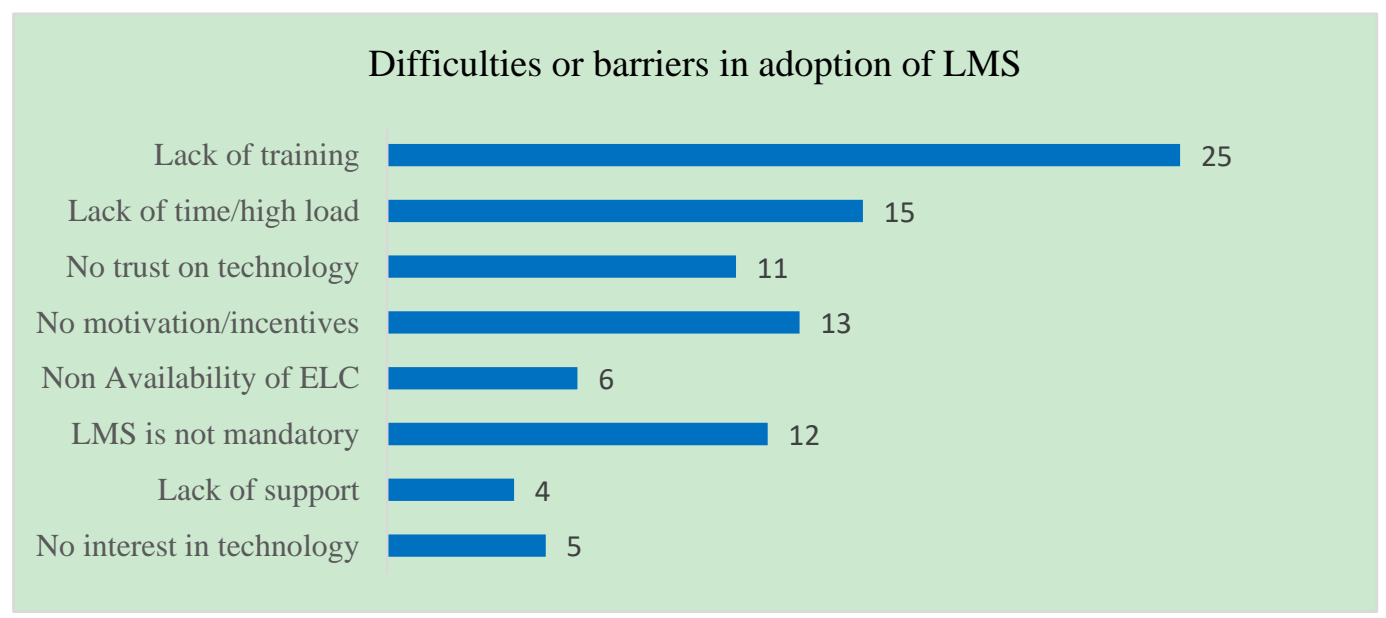

Figure 5. Barriers to adoption of LMS

It is evident from the above graph that lack of training, lack of time, lack of incentives, and lack of facilitating conditions were the key reasons why LMSs are not widely adopted. Therefore, the management should consider well-organized efforts to provide the full technical support, resources, and training to the instructors of the HEIs to improve the adoption of the LMS. 


\section{Managerial Implication}

- According to a Pilot study, it is evident that out of 39 faculty who responded, there are 23 Adopters and 16 Non-Adopters of LMS.

- Most benefits of using LMS include usefulness, ease-of-use, ease-of-interaction, and improved quality of teaching and learning.

- There are several difficulties and concerns regarding the adoption of LMS in Saudi Higher Education. Most barriers indicated by faculty include lack of training, lack of time, lack of trust in technology, and optional use of LMS.

By using the results of this study, the administrators of HEIs may encourage and convince instructors and students on how easy it is to use and how useful this new technology is for them. Thereby encouraging an increase in the use of the LMS in their teaching and learning processes.

\section{Conclusion}

Recognizing the factors that influence the adoption of technology in teaching and learning will help institutions to develop remedial strategies to minimize both internal and external barriers for effective use of LMS technology at their institutions.

This study contributes to the existing body of literature on LMS by understanding previous literature on technology adoption in teaching and learning. This research advances the literature around barriers and motivators in the adoption of LMS technology in the context of EMC, in our case, the sample being HEIs of Saudi Arabia. The HEIs continuously need to assess the difficulties faced by faculty in the adoption/usage of LMS technology and to develop strategic plans that can focus on faculty professional development, trust-building in technology, and encouragement to use LMS to get the effective use of technology provided to all faculty. Using technology with its full potential may help in improving the quality of teaching and learning.

\section{References}

Bongalos, Q., Bulaon, D., de Celedonio, L., de Guzman, A., \& Ogarte, C. (2006). University teachers' experiences in courseware development. British Journal of Educational Technology, 37, 695-704. https://doi.org/10.1111/j.1467-8535.2006.00589

Braun, V., \& Clarke, V. (2006). Using thematic analysis in psychology. Qualitative Research in Psychology, 3(2), 77-101. https://doi.org/10.1191/1478088706qp063oa

Dutton, W., Cheong, P. H., \& Amkee Park (2004). An Ecology of Constraints on e-Learning in Higher Education: The Case of a Virtual Learning Environment, Prometheus, 22(2), 131-149. https://doi.org/10.1080/0810902042000218337

Dulle, F. W., \& Minishi-Majanja, M. K. (2011). The suitability of the Unified Theory of Acceptance and Use of Technology (UTAUT) model in open access adoption studies. Information Development, 27(1), 32-45. https://doi.org/10.1177/0266666910385375

Gautreau, C. (2011). Motivational factors affecting the integration of a learning management system by faculty. The Journal of Educators Online, 8(1). January 2011 ISSN 1547-500X Publisher: Journal of Educators Online. https://doi.org/10.9743/JEO.2011.1.2

Khan, R. A., \& Adams, C. (2016). Adoption of Learning Management Systems in Saudi Higher Education Context: Study at King Fahd University of Petroleum and Minerals \& Dammam Community College. In Society for Information Technology \& Teacher Education International Conference. Vol. 2016. No. 1. (pp. 2909-2916). https://doi.org/10.1177/2158244018824506

Lakhal, S., Khechine, H., \& Pascot, D. (2013). Student behavioral intentions to use desktop video conferencing in a distance course: integration of autonomy to the UTAUT model. Journal of Computing in Higher Education, 25(2), 93-121. https://doi.org/10.1007/s12528-013-9069-3

MarketWatch: Next-Gen Learning Management System (LMS) Market Size, Share 2020 Global Leading Players, Industry Updates, Future Growth, Business Prospects, Forthcoming Developments, and Future Investments by Forecast to 2024.2020 (October https://www.marketwatch.com/press-release/next-gen-learning-management-system-lms-market-size-share-202 0 -global-leading-players-industry-updates-future-growth-business-prospects-forthcoming-developments-and-fut ure-investments-by-forecast-to-2024-2020-10-07 
Nistor, N., Lerche, T., Weinberger, A., Ceobanu, C., \& Heymann, O. (2014). Towards the integration of culture into the Unified Theory of Acceptance and Use of Technology. British Journal of Educational Technology, 45(1), 36-55. https://doi.org/10.1111/j.1467-8535.2012.01383.x

Sharma, S., Paul, A., Conway, C., Gillies, D., Nesbitt, S., Ripstein, I., Simon, I., McConnell K. Learning/Curriculum Management Systems (LCMS): Emergence of a New Wave in Medical Education. Recent Advances in Applied \& Biomedical Informatics and Computational Engineering in Systems Application 2011. Eds. Lazard M, Buikis A, Yurly S. et al. ISBN 978-1-61804-028-2. Pages 393-397.

Wang, Q., Woo, H. L., Quek, C. L., Yang, Y., \& Liu, M. (2012). Using the Facebook group as a learning management system: An exploratory study. British Journal of Educational Technology, 43(3), 428-438. https://doi.org/10.1111/j.1467-8535.2011.01195.x

Venkatesh, V., Thong, James, Y. L., \& Xu, X., Consumer Acceptance and Use of Information Technology: Extending the Unified Theory of Acceptance and Use of Technology (February 9, 2012). MIS Quarterly, Vol. 36, No. 1, 157-178, 2012. https://doi.org/10.2307/41410412

Venkatesh, V., Morris, M., Davis, G., \& Davis, F. (2003). User Acceptance of Information Technology: Toward a Unified View. MIS Quarterly, 27(3), 425-478. https://doi.org/10.2307/30036540

\section{Copyrights}

Copyright for this article is retained by the author(s), with first publication rights granted to the journal.

This is an open-access article distributed under the terms and conditions of the Creative Commons Attribution license (http://creativecommons.org/licenses/by/4.0/). 